\title{
COMPARATIVE ANALYSIS OF ALCOHOL SCLEROTHERAPY VERSUS CATHETER DRAINAGE IN THE TREATMENT OF NON-PARASITIC BENIGN LIVER CYSTS
}

\author{
Milan Radojković1,2, Saša Dimićs ${ }^{3}$ Zlatko Širić4, Ivana Dimić ${ }^{5}$ \\ Dušan Petrović ${ }^{3}$, Miroslav Stojanović1,2, Aleksandar Karanikolić1,2
}

\begin{abstract}
Non-parasitic benign liver cysts are relatively common and cause symptoms due to their growth and compression on adjacent structures. Percutaneous management, as a less invasive, cheaper, safe and effective method, represents the treatment of choice for these lesions. The aim of this study was to evaluate and compare the efficacy of singlesession alcohol sclerotherapy versus prolonged catheter drainage in the treatment of simple liver cysts. In our prospective study, 42 consecutive patients with symptomatic solitary simple liver cyst were randomized into two groups: 21 patients treated with aspiration and single-session alcohol sclerotherapy (group A), and 21 patients with aspiration and prolonged negative pressure catheter drainage (group B). Cyst volume reduction rates, lenght of hospital stay, and occurrence of complications related to the procedure were analyzed and compared. Our results indicate that prolonged negative pressure catheter drainage and single-session alcohol sclerotherapy produced similar treatment results. Nevertheless, a longer time needed for the procedure, higher costs and greater patient's discomfort, as well as the risk of higher recurrence rate, might make prolonged catheter drainage a less desirable method of treatment of simple hepatic cysts.
\end{abstract} Acta Medica Medianae 2017;56(4):45-49.

Key words: simple liver cysts, sclerosation, drainage

\author{
${ }^{1}$ University of Niš, Faculty of Medicine, Surgery Department, \\ Niš, Serbia \\ ${ }^{2}$ Surgery Clinic, Clinical Center Niš, Niš, Serbia \\ ${ }^{3}$ Surgery Department, Health Center Kosovska Mitrovica, Serbia \\ ${ }^{4}$ Radiology Institute, Clinical Center Niš, Serbia \\ ${ }^{5}$ Primary Healthcare Center, Kosovska Mitrovica, Serbia \\ Contact: Milan Radojković \\ Ul. Sestre Baković 14/28, 18000 Niš \\ E-mail: mida71@mts.rs
}

\section{Introduction}

Non-parasitic benign liver cysts, also known as symple cysts, are relatively common and affect up to $5 \%$ of people (1). These tumors can easily be distinguished from other cystic lesions such as multiple cysts arising in the setting of polycystic liver disease, parasitic or hydatid cysts, biliary cystadenomas/cystadenocarcinomas and hepatic abscesses on the basis of symptoma-tology and radiological features of the lesion (2). It is believed that these lesions have a congenital origin and develop as the result of progressive dilatation of biliary microhamartomas that fail to connect www.medfak.ni.ac.rs/amm normally to the biliary tree. They are lined by a uniform cuboidal or columnar epithelium resembling bile duct epithelium and contain fluid mimicking plasma continually secreted by the epithelial lining of the cyst. They are usually solitary, more frequent in women and right liver lobe, with the incidence increasing with age.

Most of these cysts are asymptomatic and frequently presenting as an incidental finding on abdominal ultrasound or CT scans (Figure 1). Although usually stable in size for a long time, the „mass effect" symptoms occur due to their growth and compression on the adjacent structures, causing abdominal pain arising in the right upper quadrant or epigastrium, nausea and vomiting, meteorism, early satiety and jaundice. Further, rapid enlargement of these cysts may lead to their rupture, hemorrhage or infection. Symptoms occur in approximately $15 \%$ of patients (3).

Surgical management of these lesions was the only potentially curative treatment modality for a long time and the procedures used included deroofing or fenestration, radical cystectomy (enucleation) or liver resection and, if necessary, internal bile drainage into the Roux-en-Y jejunal limb from a bile duct opening into the cyst cavity (if present). Recently, advances in minimally inavsive surgical techniques have made possible laparoscopic performance of most of these procedures (4). However, morbidity and mortality ra- 


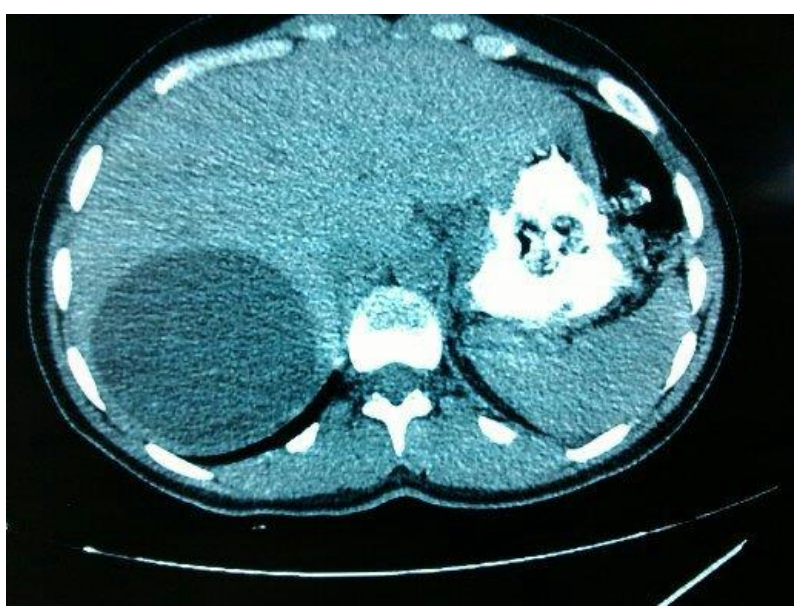

Figure 1. CT scan of a simple non-parasitic benign cyst in the liver right lobe

tes with these procedures can be considerable, in addition to high costs related to surgical management (operation, recovery, hospital stay, work disability). Today, percutaneous management as a less invasive, cheaper, safe and effective method represents the gold standard and treatment of choice for symptomatic non-parasitic benign liver cysts. It can be used as aspiration-only treatment, aspiration and injection of a sclerosing agent, or aspiration and catheter drain-age. Since frequent cyst relapses are well documented when percutaneous cyst aspiration only (without a sclerosant) is used (5), the aim of this study was to evaluate and compare the efficacy of single-session alcohol sclerotherapy versus prolonged catheter drainage in the treatment of these lesions.

\section{Material and methods}

In this prospective study, 42 consecutive patients with symptomatic solitary simple liver cyst confirmed by ultrasound and computed to-mography (CT) imaging were randomized into two groups: 21 patients were treated with aspiration and singlesession alcohol sclerotherapy (group A) and 21 patients with aspiration and prolonged negativepressure catheter drainage (group B). There were 32 women and 10 men, mean age 59.5 (ranging from 31 to 70 years). Mean duration of the disease before treatment was 14 months. Symptomatology included abdominal pain and swelling, early satiety, meteorism and jaundice. The exclusion criteria were polycystic liver disease, Caroli disease, parasitic cysts, cystic neoplasms, coagulopathy and postinterventional persistence of the symptoms. The diameters of each cyst were measured and their volumes were calculated multiplying the product of their three orthogonal diameters by 0.523 .

The patients were fasting the morning before the intervention and started oral liquid and food intake in the evening on the treatment day. All the procedures were done in local anesthesia without conscious sedation. Cyst puncture was performed under sonographic guidance, in supina- tion, using a 18-gauge needle. Vital signs (blood pressure, heart rate, partial pressure of arterial oxygen - $\mathrm{PaO}_{2}$ ) were monitored during and 2 hours after the procedures. The sample of aspirated fluid underwent bacteriological and cytological analysis and bilirubin level determination, along with contrast fluoroscopic imaging, in order to exclude any communication with the biliary system and/or peritoneal cavity (Figure 2 ).

Diluted contrast medium was injected into the cyst at a volume of $50 \%$ of aspirated cyst fluid volume. All the patients were administered intravenous saline solution with prophylactic pain relief medication during and after the procedure. In group A, a sclerosing agent, 96\% ethanol, was injected after complete fluid/contrast evacuation, along with $5-10 \mathrm{~mL}$ of $2 \%$ lidocaine (for pain relief) and left in the cyst cavity for 1 hour and then evacuated completely. The amount of alcohol used was approximately $30 \%$ of the aspirated cyst fluid volume, but did not exceed $200 \mathrm{~mL}$ (regardless of the cyst size) to avoid systemic absorption and acute intoxication. Patients were changing their

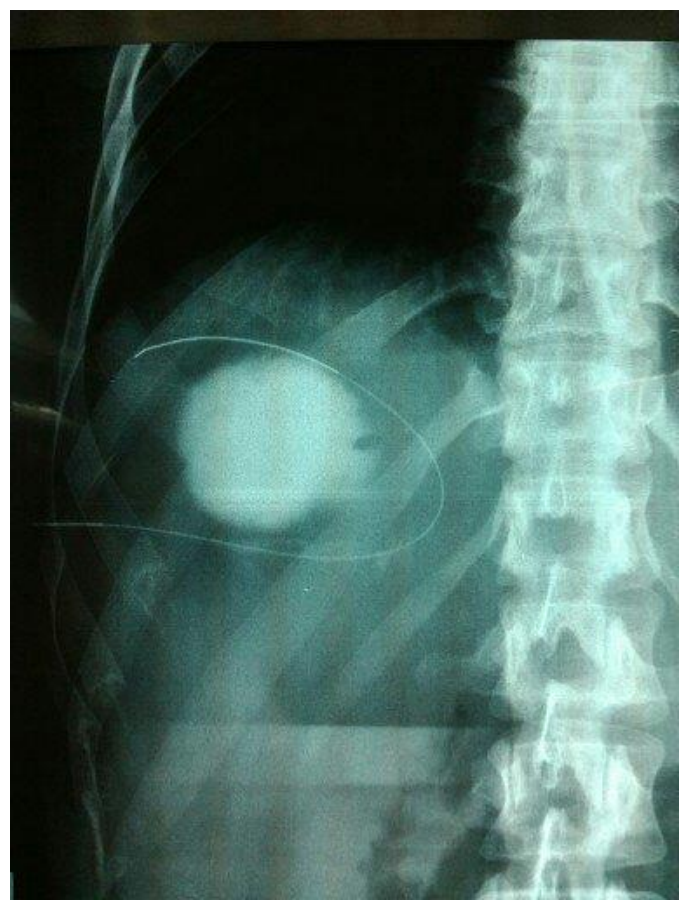

Figure 2. Contrast fluoroscopic image of a simple non-parasitic benign liver cyst.

position every 10 minutes (pronation, supination, bilateral decubitus) during sclerosation in order to assure proper and full contact of the sclerosant with the whole inner surface of the cyst cavity. In group B, using the Seldinger's method, a 6- to 8French pigtail catheter was inserted into the cyst under fluoroscopic guidance and connected to negative pressure. After complete ces-sation of cyst fluid evacuation it was removed. The followup period was 1 year $(1,3,6$ and 12 months after the intervention), when CT examination and laboratory investigation were done. Since the goal of the treatment was disappearance of the cyst, it 
was considered successful if the follow-up CT finding was a scar or normal liver tissue. Cyst volume reduction rates between the groups were compared. The laboratory parameters analy-zed before and one day and seven days after the intervention included: C-reactive protein (CRP), bilirubin, alanine-aminotransferase (ALT) and aspartate-aminotransferase (AST). Further, the lenght of hospital stay and occurrence of complications related to the procedure were analyzed and compared. In order to compare the differences in treatment results between two groups, nonparametric Mann-Whitney $U$ test was used and the statistical significance was set at $p<0.05$.

\section{Results}

The procedures in all patients were technically successful and performed without any difficulties or complications. In 25 patients (16 in group $B$ and 9 in group A), during and after the procedure, a mild local tenderness, flushing and headache or nausea occurred, all of which disappeared within 12 hours after the intervention. In 10 patients in group $A$, ethanol instillation was discontinued with 2-4 pauses lasting 15 minutes due to intractable pain. Monitored vital signs were stable in all patients except in four, who experienced a decrease in blood pressure of $20-30 \mathrm{mmHg}$. In these patients with hypotension, the procedure was terminated for 30 minutes and successfully continued after fluid supplementation without the need for dopamine infusion. Bilirubin, ALT and AST levels were not altered in any of the patients both before and after the procedure, except in 3 patients in group $B$, who had AST and ALT levels elevated on the first postprocedural day and normalized after 7 days. Further, 16 patients in group $B$ had CRP levels increased up to $210 \mathrm{mg} / \mathrm{L}$ (109 $\mathrm{mg} / \mathrm{L}$ ) one day after the intervention and 4 of them maintained elevated CRP values seven days after the procedure up to $54 \mathrm{mg} / \mathrm{L}(27 \mathrm{mg} / \mathrm{L})$. None of the cysts showed such communication nor infection of parasitic and neoplastic origin. All patients were asymptomatic a day after the procedure and were discharged from the hospital.

Before therapy, mean volume of the cysts was $699.1 \mathrm{~mL}$ (range, $112-3450 \mathrm{~mL}$ ) and the largest diameter of each cyst ranged from $6-31 \mathrm{~cm}$ (average $12 \mathrm{~cm}$ ). The mean aspirated volume of the cyst fluid was $718.3 \mathrm{~mL}$ (range 191-3011 mL). Average injected ethanol volume was $130 \mathrm{~mL}$ (range, 70-200 $\mathrm{mL}$ ). The average volume reduc-tion was $92.9 \%$ (range, 81.3-100\%) in group $A$ and $95.6 \%$ (range, $80.1-100 \%$ ) in group B. During the follow-up period, 25 cysts $(59.5 \%)$ disappeared completely (16 in group $B$ and 15 in group A). The mean residual cystic diameter after the follow-up period (on the last CT scan 12 months after the intervention) was 1.9 $\mathrm{cm}$ in group A (range $1-5 \mathrm{~cm}$ ) and $2.4 \mathrm{~cm}$ (range 1 $5 \mathrm{~cm}$ ) in group $B$. There was not any significant statistical difference in the volume reduction rates between group $A$ and group $B$. The average dura-tion of catheter drainage was 3 days (range 1-8 days).

\section{Discussion}

Although laparoscopic unroofing is often recommended by many surgeons as a method of choice in the management of non-parasitic benign liver cysts, percutaneous treatment is becoming more frequently used in recent years. This is due mainly to significant drawbacks of surgical therapy, including long average operation time (180 minutes), hospital stay (9.4 days) and relatively high morbidity rates ranging from $0-25 \%$ (6). As a minimally invasive procedure, percutaneous treatment is proven to be both safe and effective. There are a wide variety of percutaneous treatments used, most of which incluing cyst sclerosation with different agents, most frequently ethanol. Since there is a rebound phenomenon of the ablated cysts with localized fluid collections shortly after sclerotherapy (7), it is assumed that prolonged (catheter) drainage of the cyst (fluid) cavity would ensure complete "drying" of the cyst, which is a prerequisite for its successful reduction. On the other hand, secretion of the epithelial cell lining may lead to a high frequency of cyst recurrence when aspiration and drainage alone are applied (8). According to several studies, multiple alcohol instillations with different time intervals between them are recommended, because this multiple sclerotherapy technique yields better results than single-session sclerosation with reduced recurrence rate (9). However, the disadvantages of multiple session technique include: too much time for repeated aspiration and injection procedures and therefore greater patient's discomfort, higher cost and increased risk of ethanol leakage (10). Moreover, a number of studies documented that single-session alcohol sclerotherapy with widely variable time of exposure to the sclerosant (from 10 minutes to 4 hours) was as effective as multiple-session technique, being thus a sufficient and less risky method (11-13). The results of our study did not demonstrate any clear advantages of either of the analyzed and compared methods, since there were no statistical differences in average volume reduction between ethanol sclerotherapy and catheter drainage. However, both procedures were highly effective treatment modalities, considering the very satisfactory mean residual cystic diameter after the follow-up period in all our patients (1.9 and 2.4, respecti-vely, for groups $A$ and B).

All the side effects of this procedure, i.e. symptoms that occurred in our patients, are well known, expected and can be attributed to acute alcohol intoxication and/or invasiveness of the intervention (cyst puncture, catheter placement). Since the majority of patients with symptoms during and after the procedure were from group $B$ (16 versus 9$)$, we tend to regard catheter drainage as a more invasive method. The exception refers to occurrence of pain and hypotensia during the procedure in 10 group $A$ patients, which are explained by the corosive effects of ethanol and acute intoxication, but these are to be expected as well. The alteration of laboratory pa- 
rameters are also observed only in group $B$ patients. A transitory increase of AST and ALT levels in three patients might indicate a more invasive nature and poorer tolerance of catheter drainage compared to alcohol sclerosation, but it should not be considered a clinically significant side effect, since the levels of these two parameters returned to normal values after 7 days. A persistently increased CRP level could be explained as an expected host defense response, i.e. inflammatory reaction to catheter tube as a foreign body.

\section{Conclusion}

Percutaneous treatment is a safe and effective alternative to surgery for the management of symptomatic non-parasitic benign liver cysts. The lack of significant statistical difference of the volume reduction rates and mean residual cystic diameter after the follow-up period between group $A$ and group $B$, as well as the similar incidence of side-effects lead us to the conclusion that prolonged catheter drainage with negative pressure and single-session alcohol sclerotherapy had similar results as treatment options. Nevertheless, longer time needed for the performance, higher costs and greater patient discomfort, as well as the risk of higher recurrence rate, might make prolonged catheter drainage a less desirable method of simple hepatic cyst treatment.

\section{References}

1. Civello IM, Matera D, Maria G, Nigro C, Brandara F, Brisinda G. Laparoscopic fenestration of symptomatic non-parasitic cysts of the liver. Hepatogastro enterology 2005; 52(63):849-51. [PubMed]

2. Arnold $\mathrm{HL}$, Harrison SA. New advances in evaluation and management of patients with polycystic liver disease. Am J Gastroenterol 2005; 100(11):256982. [CrossRef] [PubMed]

3. Schachter $P$, Sorin $V$, Avni $Y$, Shimonov $M$, Friedman $V$, Rosen $A$, et al. The role of laparoscopic ultrasound in the minimally invasive management of symptomatic hepatic cysts. Surg Endosc 2001; 15(4):364-7. [CrossRef] [PubMed]

4. Szabo LS, Takacs I, Arkosy P, Sapy P, Szentkereszty Z. Laparoscopic treatment of nonparasitic hepatic cysts. Surg Endosc 2006; 20(4): 595-7. [CrossRef] [PubMed]

5. Blonski WC, Campbell MS, Faust T, Metz DC. Successful aspiration and ethanol sclerosis of a large, symptomatic, simple liver cyst: case presen tation and review of the literature. World J Gastroenterol 2006; 12(18):2949-54. [CrossRef] [PubMed]

6. Tagaya N, Nemoto T, Kubota K. Long-term results of laparoscopic unroofing of symptomatic solitary nonparasitic hepatic cysts. Surg Laparosc Endosc Percutan Tech 2003; 13(2):76-9. [CrossRef] [PubMed]

7. Larssen TB, Viste A, Jensen DK, Sondenaa K, Rokke $O$, Horn A. Single-session alcohol sclerotherapy in benign symptomatic hepatic cysts. Acta Radiol 1997; 38(6):993-7. [CrossRef] [PubMed]

8. Saini S, Mueller PR, Ferrucci JT Jr, Simeone JF, Wittenberg J, Butch RJ. Percutaneous aspiration of hepatic cysts does not provide definitive therapy. AJR Am J Roentgenol 1983; 141(3):559-60. [CrossRef] [PubMed]

9. vanSonnenberg $E$, Wroblicka JT, D'Agostino HB, Mathieson JR, Casola G, O'Laoide R, et al. Symptomatic hepatic cysts: percutaneous drainage and sclerosis. Radiology 1994; 190(2):387-92. [CrossRef] [PubMed]

10. Hanna RM, Dahniya MH. Aspiration and sclero therapy of symtomatic simple renal cysts: value of two injections of a sclerosing agent. AJR Am J Roentgenol 1996; 167(3):781-3. [CrossRef] [PubMed]

11. Larssen TN, Rosendahl K, Horn A, Jensen DK, Rorvik J. Single-session alcohol sclerotherapy in symptomatic benign hepatic cysts performed with a time of exposure to alcohol of 10 minutes: initial results. Eur Radiol 2003; 13(12):2627-32. [CrossRef] [PubMed]

12. Chung $\mathrm{BH}$, Kim JH, Hong $\mathrm{CH}$, Yang SC, Lee MS. Comparison of single and multiple sessions of percutaneous sclerotherapy for simple renal cyst. BJU Int 2000; 85(6):626-7. [CrossRef] [PubMed]

13. Simonetti G, Profili S, Sergiacomi GL, Meloni GB, Orlacchio A. Percutaneous treatment of hepatic cysts by aspiration and sclerotherapy. Cardiovasc Intervent Radiol 1993; 16(2):81-4. [CrossRef] [PubMed] 


\title{
KOMPARATIVNA ANALIZA ALKOHOLNE SKLEROTERAPIJE I KATETERSKE DRENAŽE U LEČENJU NEPARAZITARNIH BENIGNIH CISTI JETRE
}

\author{
Milan Radojković1,2, Saša Dimić3 ${ }^{3}$ Zlatko Širić4, Ivana Dimić5, \\ Dušan Petrović 3 , Miroslav Stojanović1,2, Aleksandar Karanikolić1,2
}

\author{
${ }^{1}$ Univerzitet u Nišu, Medicinski fakultet, Katedra za hirurgiju, Niš, Srbija \\ ${ }^{2}$ Klinika za hirurgiju, Klinički centar Niš, Niš, Srbija \\ ${ }^{3}$ Odeljenje hirurgije, Zdravstveni centar Kosovska Mitrovica, Srbija \\ ${ }^{4}$ Institut za radiologiju, Klinički centar Niš, Niš, Srbija \\ ${ }^{5}$ Dom zdravlja, Kosovska Mitrovica, Srbija \\ Kontakt: Milan Radojković \\ UI.Sestre Baković 14/28, 18000 Niš \\ e-mail: mida71@mts.rs
}

Neparazitarne benigne ciste jetre su relativno česte i izazivaju simptome u slučaju naglog rasta i kompresije na okolne strukture. Perkutani pristup, kao manje invazivan, jeftiniji, sigurniji i efikasniji terapijski modalitet, danas predstavlja metod izbora u lečenju ovih lezija. Cilj naše studije bio je da utvrdimo i uporedimo efikasnost jednokratne perkutane skleroterapije alkoholom i kontinuirane kateterske drenaže. $U$ prospektivnu studiju uključena su 42 bolesnika koja su naizmenično podeljena u dve grupe: grupa A od 21 bolesnika lečenog perkutanom aspiracijom sadržaja ciste i alkoholnom sklerozacijom u jednom aktu i grupa B od 21 bolesnika lečenog aspiracijom i kontinuiranom kateterskom drenažom pod negativnim pritiskom. Upoređivani su učestalost i opseg redukcije zapremine cisti, dužina boravka u bolnici i pojava periinterventnih komplikacija. Dobijeni rezultati ukazuju da kateterska drenaža sa negativnim pritiskom i alkoholna skleroterapija u jednom aktu imaju sličnu efikasnost kao terapijske opcije. Ipak, duže vreme kompletiranja procedure (nošenje katetera), viša cena i veća nelagodnost za bolesnike, kao i veći rizik od recidiva, mogli bi biti atributi koji katetersku drenažu čine manje pogodnom metodom za lečenje prostih cisti jetre.

Acta Medica Medianae 2017;56(4):45-49.

Ključne reči: proste ciste jetre, sklerozacija, drenaža 